\title{
Speleothems in the dry cave parts of the Gamslöcher- Kolowrat Cave, Untersberg near Salzburg (Austria)
}

\author{
Anna Bieniok ${ }^{1}$, Georg Zagler $^{2}$, Uwe Brendel ${ }^{2}$ and Franz Neubauer ${ }^{3}$
}

\begin{abstract}
:
Bieniok A., Zagler G., Brendel U. and Neubauer F. 2011. Speleothems of the Kolowrat Cave, Austria International Journal of Speleology, 40 (2), 117-124 Tampa, FL (USA). ISSN 0392-6672. DOI 10.5038/1827-806X.40.2.4

New, remarkably dry parts of the Gamslöcher-Kolowrat Cave at 728 to $853 \mathrm{~m}$ depth have been explored in the Untersberg near Salzburg in Austria. This region is called the Desert, its greatest cavity is called the White Hall. The new cave part is characterized by various white speleothems. The predominant ones are snow-like calcite powder with an extremely low density, and fine gypsum needles. Gypsum also occurs in the form of balls stuck to vertical walls. In addition, fluorescent hydromagnesite crusts, $\mathrm{Mg}_{5}\left(\mathrm{CO}_{3}\right)_{4}(\mathrm{OH})_{2} \cdot 4 \mathrm{H}_{2} \mathrm{O}$, as well as the sodium sulfate mineral mirabilite were identified in this part of the cave. Mirabilite and gypsum needles differ from the gypsum balls in their isotopic sulfur signature $\left(\delta^{34} \mathrm{~S}\right.$ of $-16.9 \%$ and $-18.4 \%$ vs. $+2.9 \%$ ). The unusually low sulfur isotopic compositional values are tentatively explained by a source of bacteriogenetic sulfur from sulfides.
\end{abstract}

Keywords: calcite powder, mirabilite, thenardite, gypsum, sulfur isotope analysis, Untersberg, Salzburg, Austria

Received 31 December 2010; Revised 2 February 2011; Accepted 5 March 2011

\section{INTRODUCTION}

The Untersberg is a $70 \mathrm{~km}^{2}$ large karst massif southwest of the city of Salzburg in Austria (Fig. 1). The border between Salzburg and Bavaria (Germany) crosses the karst plateau in a SW NE direction. The highest peaks of the high, rugged massif are the German Berchtesgadener Hochthron (1972 m) and the Austrian Salzburger Hochthron (1853 m). The 17 $\mathrm{km}^{2}$ large karst plateau, which is characterized by dolines, shafts and pits, can be reached by a cable car. General information on the locality can be found at www.untersberg.net (Uhlir, 2010). More than 300 caves have been described from the Untersberg massif, among them are ice-caves and caves with remarkable depths (Klappacher \& Mais, 1975). The most famous Untersberg cave is the Kolowrat Cave (Austrian Cave Register: 1339/1), which was well-known as an easily accessible ice-cave through reports of tourist guides from Salzburg one hundred years ago. The entry of the cave was enlarged and access made easier by a steep track, allowing ice-skating in the entrance hall of the cave to become a popular enjoyment. In 1979, a connection to the nearby Gamslöcher Cave was

\footnotetext{
${ }^{1}$ University of Salzburg, Dept. Materials Research \& Physics, Hellbrunnerstr. 34, A-5020 Salzburg, Austria

${ }^{2}$ Landesverein für Höhlenkunde Salzburg, Schloss Hellbrunn, Obj. 9, A-5020 Salzburg, Austria

${ }^{3}$ University of Salzburg, Dept. of Geography \& Geology , Hellbrunnerstr. 34, A-5020 Salzburg, Austria
}

found, and in 2004 the Salzburgerschacht, a vertical cave near the Salzburger Hochthron with a depth of $606 \mathrm{~m}$, was joined with the Gamslöcher-Kolowrat Cave (Fig. 1). Zehentner et al. (2006) give a wellarranged historical overview on the discovery of the cave system. In recent explorations by Georg Zagler, a westward extension of several kilometres was found, which brings the known length of the cave system to more than $33 \mathrm{~km}$ (Zehentner, 2010). The deepest point of the cave is now $1119 \mathrm{~m}$ below the surface. The deep parts of the Kolowrat Cave can be visited only in the cold season when the water level in the cave system is low. This is now possible due to a new winter access to the cave near the top station of the Untersberg cable car.

Sinter formations are not rare in the GamslöcherKolowrat Cave system but their occurrences are rather limited locally. Haseke-Knapczyk (1989) reports on dripstone cascades and draperies in Tropfsteingang and Walkerpfeiler, but notes that similar formations are absent in the Salzburgerschacht. During the last speleological explorations unexpectedly dry cave parts were discovered at an elevation of ca. 1000 to 1125 $\mathrm{m}$, which are rich in fine white-coloured speleothems, and hardly resemble the other parts of the cave. In this newly discovered area, low passages alternate with large halls of 10 to $40 \mathrm{~m}$ in height over a total length of $4 \mathrm{~km}$. The inner part of the labyrinth does not show any indication of dripping water. Moreover, the area is characterized by stronger air currents than observed in other parts of the cave. In wintertime, the preferred airflow direction is from $\mathrm{N}$ to $\mathrm{S}$. Due to its 


\section{Gamslöcher-Kolowrat Cave System}

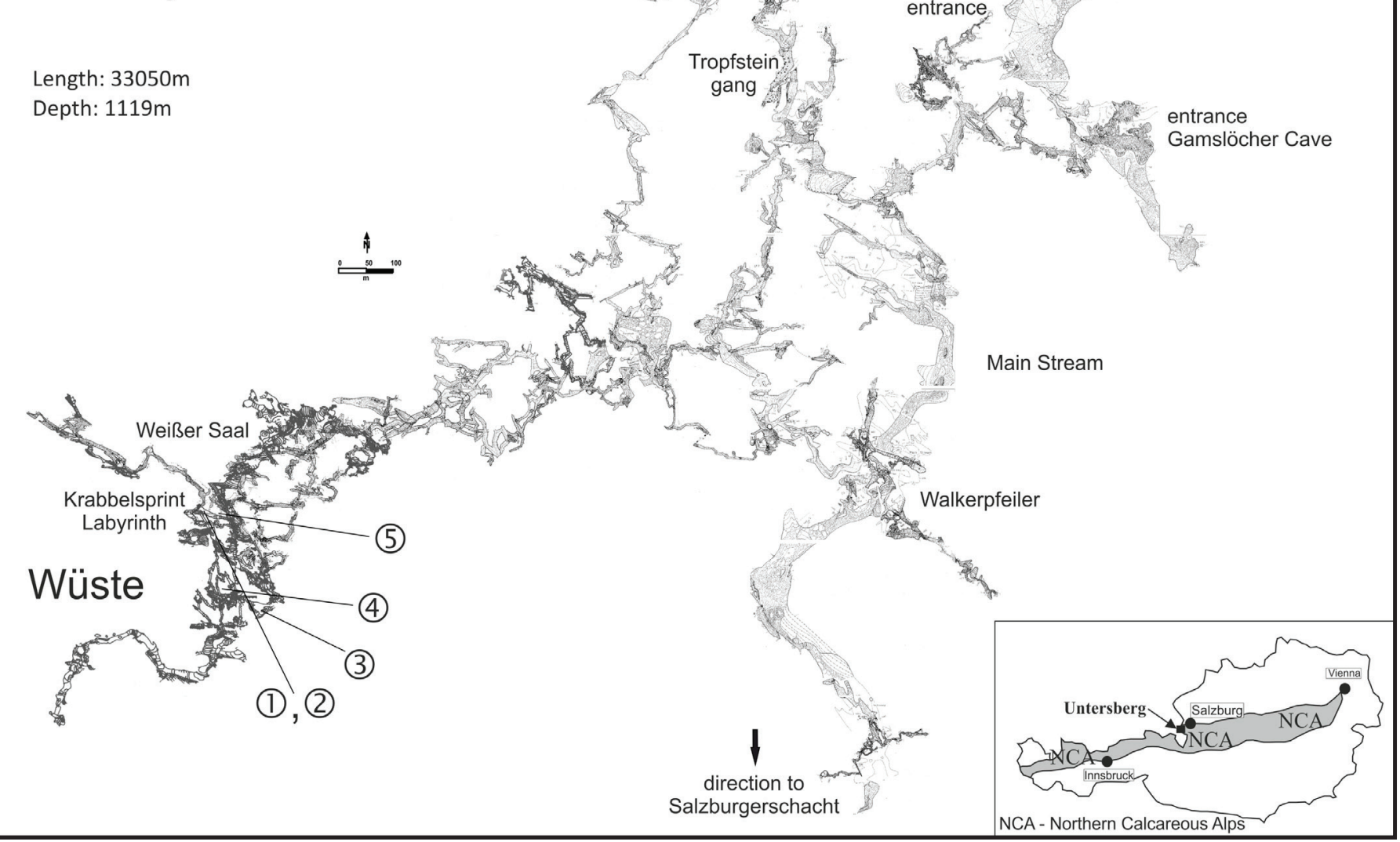

Fig. 1. Drawing of the Gamslöcher-Kolowrat Cave system with the newly-discovered, western part Wüste (Desert). The insert shows a map of Austria with the Northern Calcareous Alps (NCA) and the location of the Untersberg near Salzburg.

aridity the area was called the Wüste (Desert). A map of the location (insert) and the whole cave system with the newly-discovered region in the western part is shown in Fig. 1.

The particularly remarkable aspect of the dry cave parts is their light colour caused by white crusts and coverings on the walls, on the ceiling, and on the ground. Acicular crystals and spherical structures, as well as fine powder, cover these surfaces. For this reason, the main cavity in the Desert was named the Weißer Saal (White Hall). Preliminary results on some of the cave minerals were reported by Bieniok et al. (2010) and by Bieniok \& Zagler (2010). In the present investigation a comprehensive mineralogical study of the speleothems of this remarkably dry part of the Gamslöcher-Kolowrat Cave system was performed.

\section{GEOLOGICAL SETTING}

The Untersberg is the foremost mountain at the northern rim of the Alps and belongs to the UpperJuvavic nappe system of the central Northern Calcareous Alps (NCA). Geological formations of the Untersberg generally dip gently to the NW, and comprise from base to top the Permian to Lower Triassic Haselgebirge Formation and Middle-Upper Triassic Hallstatt facies type pelagic limestones (Hallstatt Limestone) and marls (Zlambach Formation), representing the Lower Juvavic nappe (Fig. 2; Schlager, 1930; Tollmann,
1985 and references therein). The Haselgebirge Formation is an evaporate formation with abundant clastic mudstone/shale, rock salt and various sulfates including gypsum, anhydrite and polyhalite (Spötl \& Pak, 1996; Leitner et al., 2011 and references therein). Overlying this is the thick Middle Triassic Lower Ramsau Dolomite Formation, overlain by the lowermost Upper Triassic Raibl/Cardita Formation and associated overlying Upper Ramsau Formation with evaporitic limestone and dolomite. The top layer consists of the thick Dachstein Limestone, which also forms the karst plateau on top of the Untersberg. The Raibl Formation is commonly rich in sulfides within dark/black shale. The overlying evaporitic cellular limestones and dolomite (Upper Ramsau Fm.), locally called rauhwacke, contain gypsum. Along the northern edge, thin Middle Jurassic Hierlatz and Upper Jurassic Plassen Limestone Formations conclude the stratigraphic successions. In general, detailed modern sedimentologic and stratigraphic investigations are missing for the Triassic section of the Untersberg. The Gamslöcher-Kolowrat Cave is mainly developed within the Dachstein Limestone, and - at least in some portions - within the underlying Raibl/ Cardita Formation and Upper Ramsau Dolomite. The formations dip to the NW, as does the cave system. However, detailed and systematic investigations are needed to clarify this relationship. 


\section{SAMPLE COLLECTION}

Only small amounts of speleothems were sampled and removed from the cave to perform mineralogical analyses. The cave minerals were completely sealed in air-tight tubes for transportation. Samples were collected at five different locations in the Desert between 1020 and $1120 \mathrm{~m}$ altitude. The localities are marked with numbers 1 to 5 in the cave map in Fig. 1. The most striking cave mineral in the dry parts is the white snow-like powder, which covers all surfaces in this part of the cave. The powder fills the air after ventilation (see Fig. 3). Neither crystal size nor the crystal morphology is visible to the naked eye. Calcite powder 1-W378 (the first digit refers to the location marked in the map) was taken from a small conduit of the Krabbelsprint-Labyrinth at an elevation of 1108 $m$ where the steady air flow was very strong from the north to the south. Gypsum needles occur mainly in the dry parts of the cave system: colorless, white, yellow or reddish-brown, in the form of thin fibers (like cave hair) or as acicular crystals. Remarkably large crystals of gypsum were found in the transition zones between damp and dry areas as in the border area of the White Hall. Transparent, well formed gypsum needles of ca. $40 \mathrm{~mm}$ length and $0.5 \mathrm{~mm}$ width were sampled in niches on the bottom of the White Hall near the NE-entry (2-W63) at $1031 \mathrm{~m}$ altitude (Fig. 4). Near this location hard, white crusts on the walls attract attention showing bluish-white fluorescence under ultra-violet (UV) light. These crusts are widely spread in the White Hall (Fig. 5). The hollow crusts

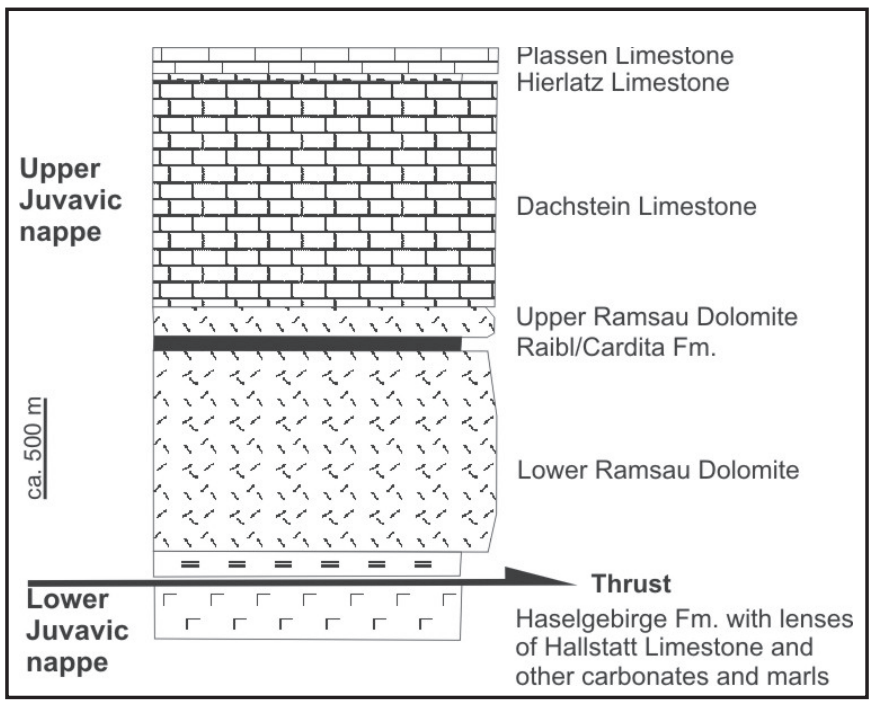

Fig. 2. Tectonostratigraphy of the Untersberg massif. The dry part of the Gamslöcher-Kolowrat Cave described in the text is mostly near the base of the Dachstein Limestone.

have inner layers of orange-brown, blocky crystals. Sample 3-W62 (Fig. 6) was taken near the NE entry of the White Hall. A small pile of white crystals is located on the loamy, red ground (presumably allochtonous cave sediment) in the SE part of the White Hall at $1035 \mathrm{~m}$ (sample 4-W67, Fig. 7). The sole deposit has an extension of $0.2 \mathrm{~m}$ in diameter. The crystal lustre is more brilliant than the other white speleothems. Other

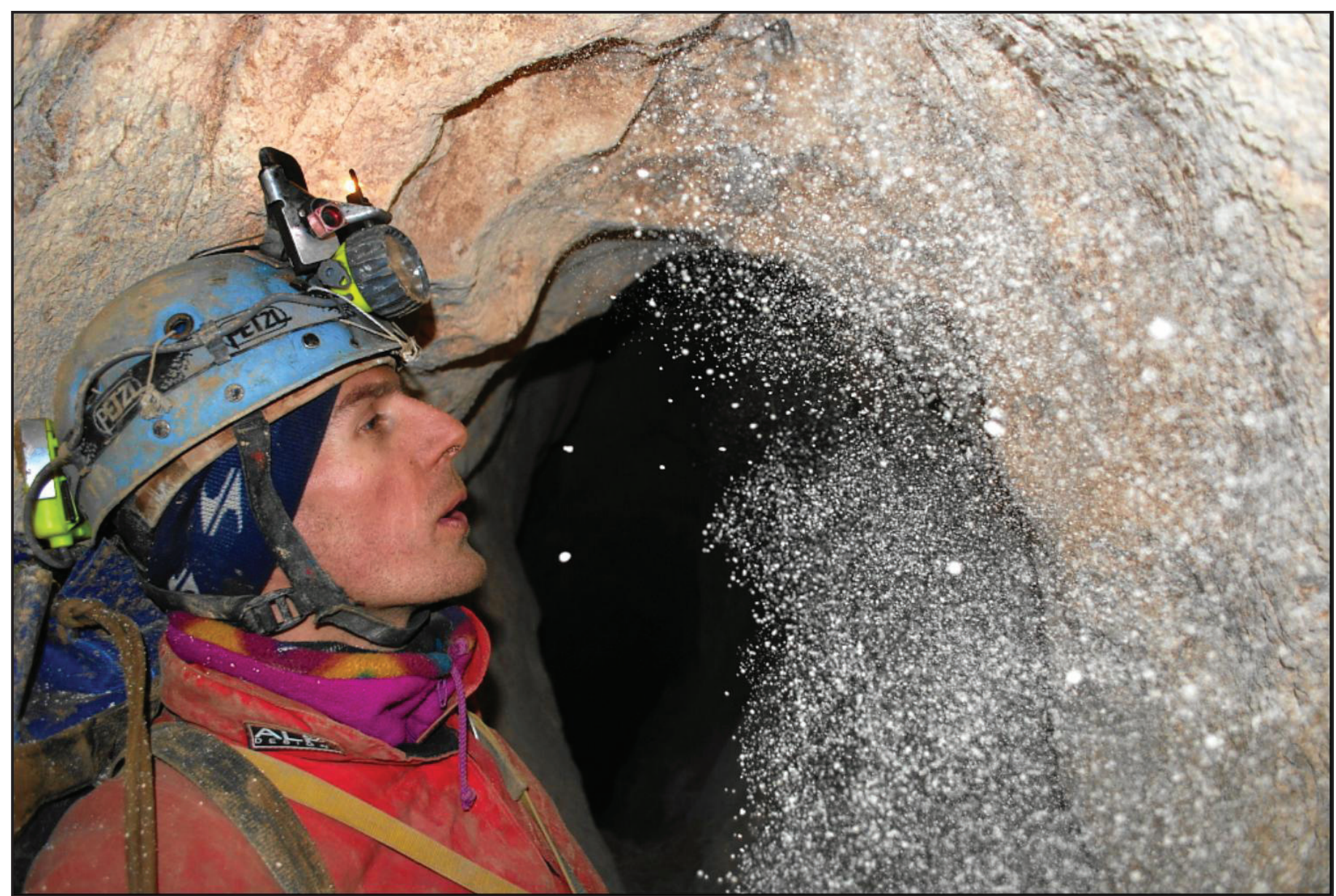

Fig. 3. Calcite powder (sample 1-W378) in the Desert. Photo by Dirk Peinelt. 


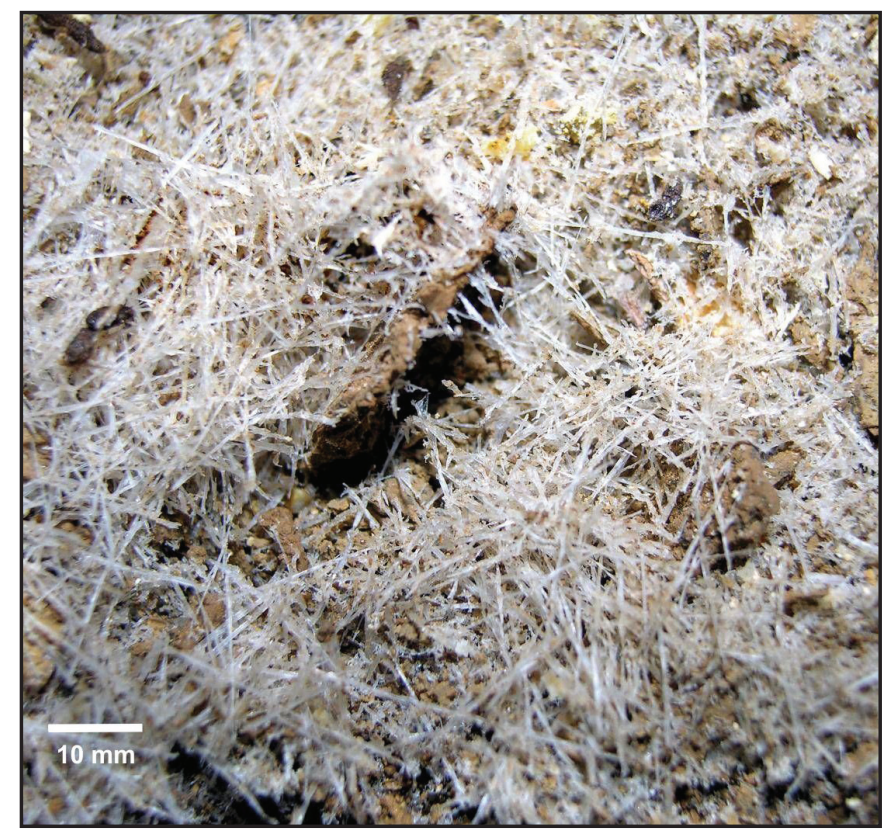

Fig. 4. Gypsum needles up to $40 \mathrm{~mm}$ length on the ground in the White Hall (sample 2-W63). Photo by Dirk Peinelt.

remarkable cave mineral deposits are hemispherical balls of white crystals, which occur on the walls ca. 1 $\mathrm{m}$ above the ground near the Krabbelsprint-Labyrinth at ca. $1070 \mathrm{~m}$ altitude (Fig. 8). Many of these balls are found on the cave walls in this area, which is possibly a former siphon zone because it is the lowest point where three corridors intersect. The ceiling in this chamber is overabundantly decorated with flowstone crusts, and tinted reddish-brown by remains of loam. The balls are white without any trace of loam, their diameters are between 0.15 and $0.2 \mathrm{~m}$, and they are associated with small gypsum needles. Sample 5 -W622 is a fragment of such a ball. The gypsum balls must have been formed after the last flooding of the siphon zone, because they show no impurities with red loam as the flowstone crusts on the ceiling.

\section{METHODS}

X-ray diffraction (XRD) measurements were performed with a Siemens D500 powder diffractometer to identify the mineralogical composition of the samples. The diagrams were recorded with graphitemonochromatized CuKa-radiation from $3^{\circ}$ to $75^{\circ} 2 \theta$ using a step size of $0.02^{\circ} 2 \theta$ and a step time of $2 \mathrm{~s}$. Five samples were analyzed with a LEICA stereoscan 430 scanning electron microscope (SEM). They were coated with gold to provide electrical conductivity of the crystal surfaces. The SEM is equipped with an X-ray energy dispersive system (Röntec) to perform qualitative chemical analyses. The operating conditions were $20 \mathrm{kV}$ high voltage, sample distance of $25 \mathrm{~mm}$, and sample currents between 80 and 200 pA. XRD and SEM analyses were performed at the University of Salzburg. The density of sample 1-W378 was estimated by weighing the powder in a volume-calibrated container. The ${ }^{34} \mathrm{~S} /{ }^{32} \mathrm{~S}$ ratio of the sulfate samples were measured using a Delta V Isotope Ratio Mass Spectrometer (IRMS) at the University of South Florida Stable Isotope Lab by

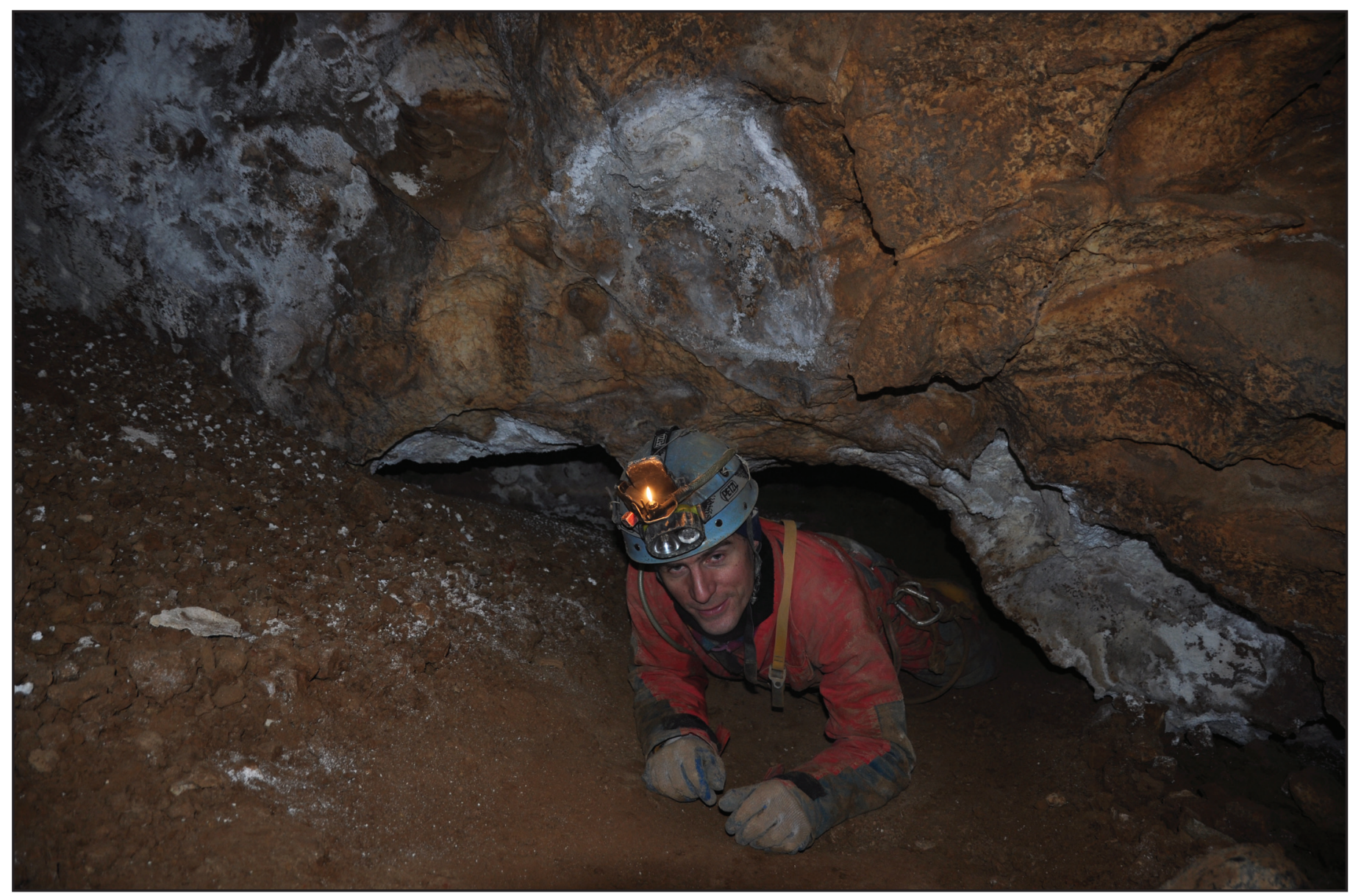

Fig. 5. NE-entry of the White Hall with hydromagnesite crusts. Photo by Dirk Peinelt. 
Bogdan P. Onac. The results are given in delta (ठ)notation with respect to the Cañon Diablo Troilite (CDT) standard. Isotope ratios were measured by coupled Elemental Analysis EA-IRMS (Costech ECS 4100), which quantitatively converts $\mathrm{S}$ in the mineral sample to $\mathrm{SO}_{2}$, and the isotope ratio of $\mathrm{SO}_{2}$ gas eluting from the chromatographic column of the EA analyzed (Grassineau et al., 2001). The standards used for analysis were IAEA SO-5 $\left(\delta^{34} \mathrm{~S}=+0.5 \%\right.$ o $)$ and IAEA SO-6 $\left(\delta^{34} \mathrm{~S}=-34.1 \%\right.$ o) for sulfates. The reproducibility between replicate standards was $<0.1 \%$. The results are normalized to the international sulfur standard $\mathrm{V}-\mathrm{CDT}$ (Vienna-CDT) using $\delta^{34} \mathrm{~S}$ values of the four IAEA standards. Confirmation of our $\delta^{34} \mathrm{~S}$ values was given by Victor Polyak at the University of New Mexico, USA.

\section{RESULTS AND DISCUSSION}

The white snow-like powder (1-W378), which occurs in most parts of the dry cave area, was identified by $\mathrm{X}$-ray diffraction as calcite, $\mathrm{CaCO}_{3}$. Only minor amounts of gypsum and quartz were detectable. The calcite powder has a remarkably low density of only $0.075 \mathrm{~g} / \mathrm{cm}^{3}$, a value which is comparable to that of fresh snowfall. The material has a fractal dimension in the nanometer scale (100 to $300 \mathrm{~nm}$ wide). Even at high magnification in the scanning electron microscope single calcite grains can hardly be recognized (Fig. 9a). Cave powder is known as a common deposit in caves, but its size normally ranges between 10 and $50 \mu \mathrm{m}$. Furthermore, cave powder is attributed to most of the phosphates, oxides, and hydroxides and to some silicates (Hill \& Forti, 1997) but not to calcite. Noteworthy is the extremely low density of the calcite powder, causing its appearance as dispersible dust. The most probable reason for the morphology and low density of the calcite powder is the strong ventilation in this part of the cave. The origin of the strong airflow is presumably the stackeffect resulting from density differences of air due to variations in moisture and temperature. During wintertime many blow-out openings exist in the karst plateau, and air suctioning occurs through openings in the northern mountainside of the Untersberg. The buoyancy forces result in a very constant airflow in a $\mathrm{N}$ to $\mathrm{S}$ direction, as long as the temperature difference is more than $15{ }^{\circ} \mathrm{C}$, which means a winter temperature of less than $-10^{\circ} \mathrm{C}$. The aridity of the area may be the result of fault-zones which prevent the access of water to this cave area. In addition, seasonal airflow due to the closure of siphons at higher water levels can play a major role.

The white, cauliflower-like, fluorescent crusts (3W62) found near the NE-entry of the White Hall are composed of hydromagnesite $\mathrm{Mg}_{5}\left(\mathrm{CO}_{3}\right)_{4}(\mathrm{OH})_{2} \cdot 4 \mathrm{H}_{2} \mathrm{O}$. The SEM investigation shows that the crusts are made up of lamellar aggregates of thin plates, ca. $10 \cdot 10 \mu \mathrm{m}^{2}$ and $0.5 \mu \mathrm{m}$ in width. Fig. 9b shows the lamellae with 3000-fold magnification. The orangebrown, blocky crystals on the inner side of the crusts are aragonite, the orthorhombic variety of $\mathrm{CaCO}_{3}$. Hydromagnesite in association with nesquehonite $\mathrm{MgCO}_{3} \cdot 3 \mathrm{H}_{2} \mathrm{O}$ was formerly described for upper parts of the Salzburgerschacht in a breakdown zone (Kirchner $\&$ Simonsberger, 1982). In the sample 3-W62 of the

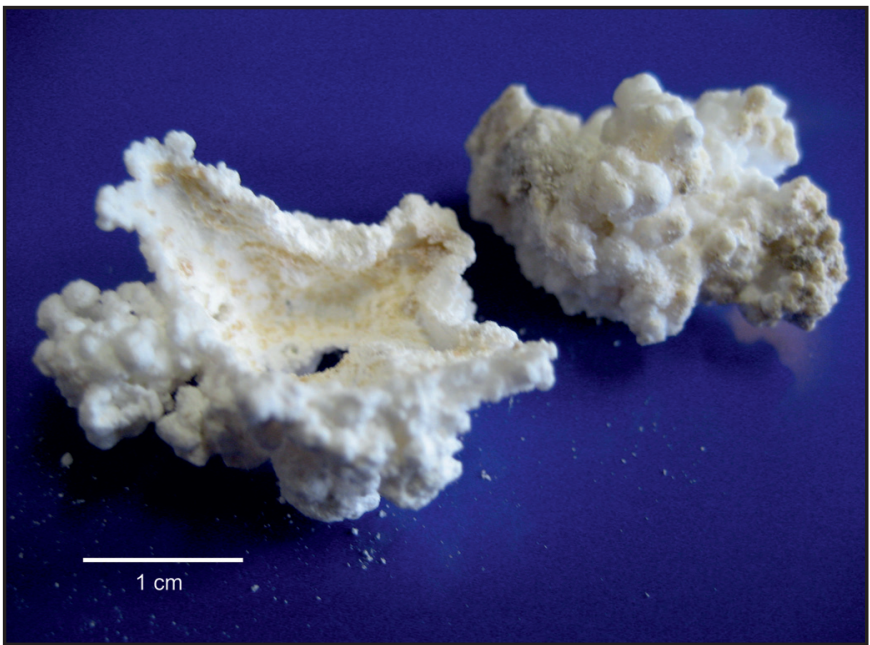

Fig. 6. White crusts composed of hydromagnesite (3-W62); the pieces have dimensions of 30 and $25 \mathrm{~mm}$, respectively.

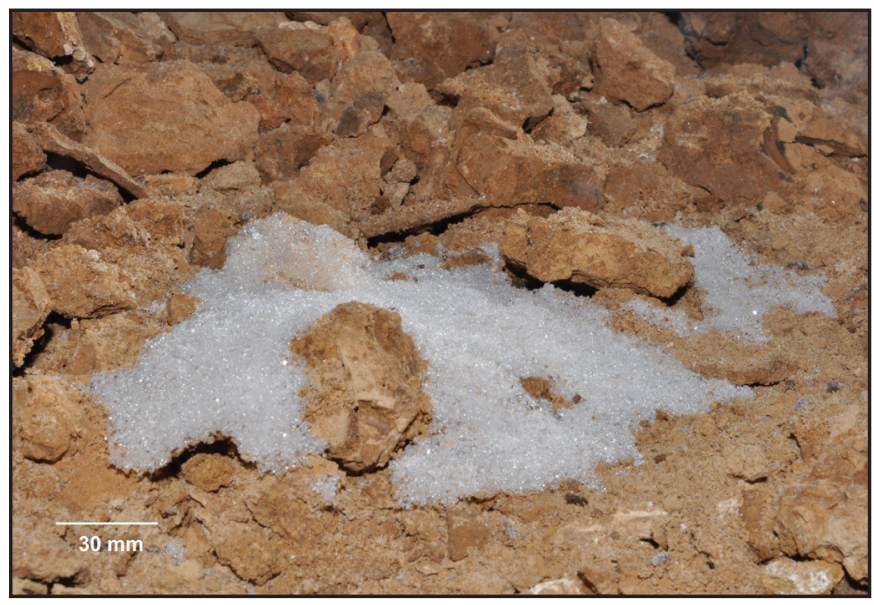

Fig. 7. Bright crystals of mirabilite in the White Hall (4-W67); the size of the deposit is ca. $0.2 \mathrm{~m}$. Photo by Dirk Peinelt.

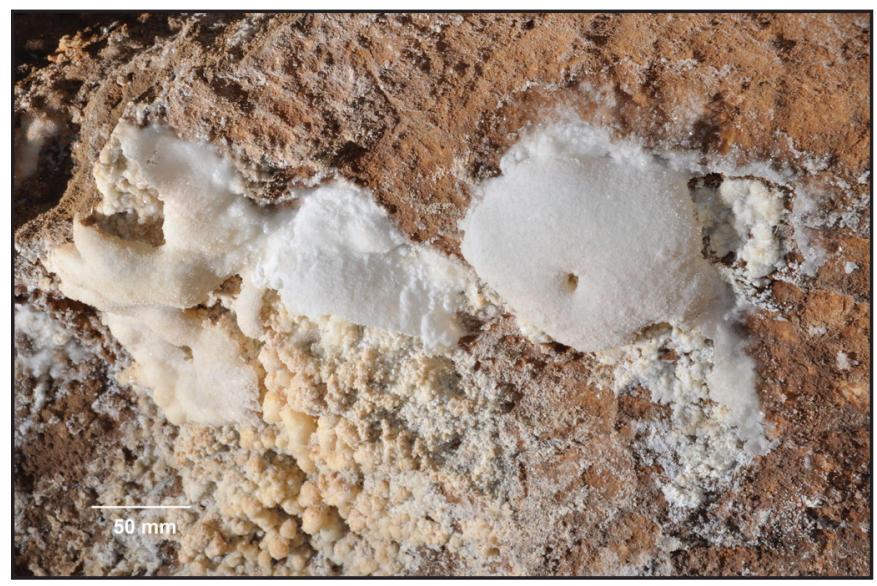

Fig 8. Gypsum balls of max. $150 \mathrm{~mm}$ in diameter on the walls in the Krabbelsprint-Labyrinth (5-W622). Photo by Dirk Peinelt.

White Hall nesquehonite is not detectable.

Gypsum, $\mathrm{CaSO}_{4} \cdot 2 \mathrm{H}_{2} \mathrm{O}$, occurs in different morphologies in the dry part of the GamslöcherKolowrat cave system. The needle-like crystals are composed of gypsum (sample 2-W63). The XRDdiagram shows small contaminations of quartz and muscovite, both components of the underlying cave sediments. Another deposit of gypsum occurs in the Krabbelsprint-Labyrinth. Hollow, hemispherical 


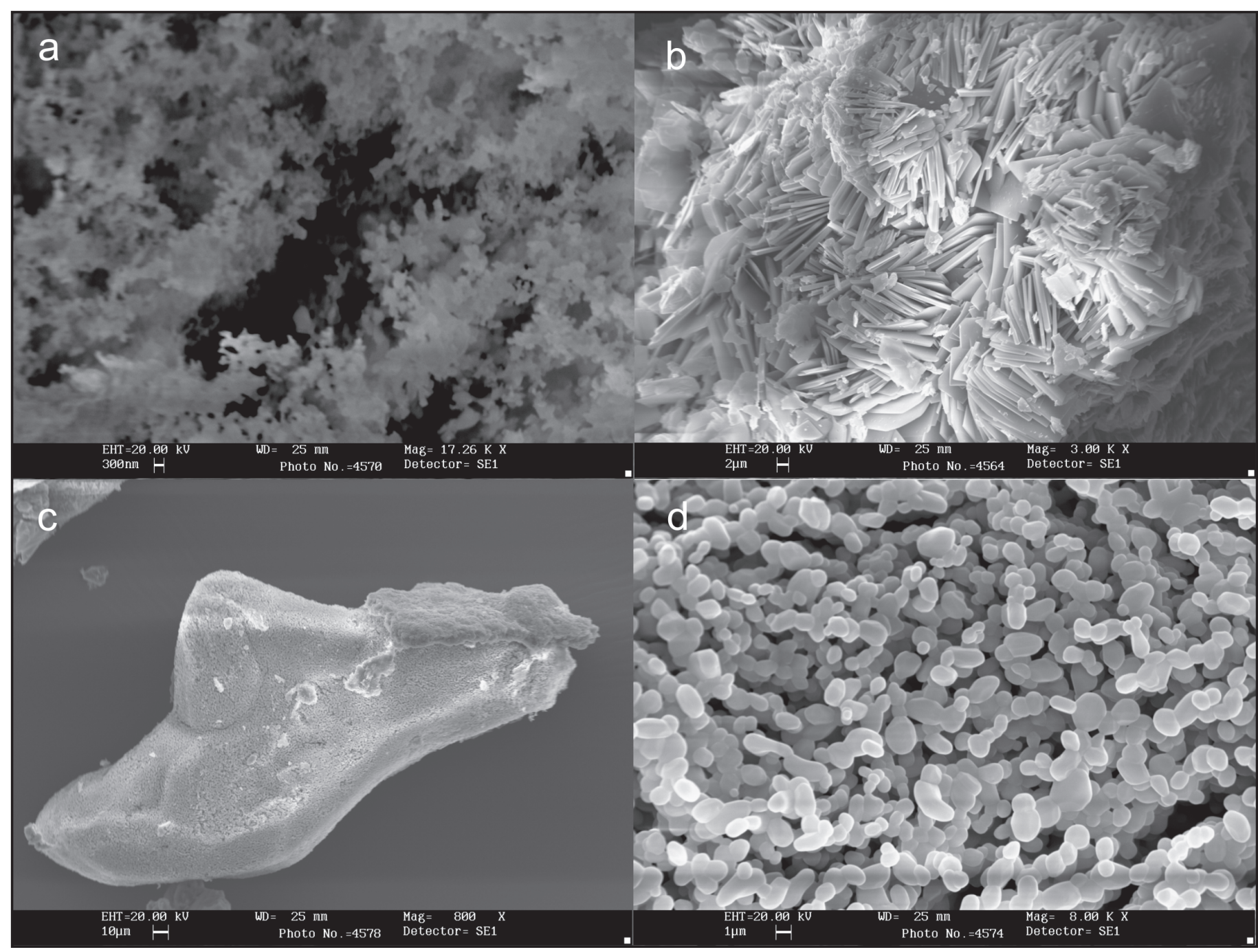

Fig. 9.a-d: a.) SEM-micrograph showing the fractal morphology of the calcite powder (x 17260); b.) SEM micrograph of hydromagnesite lamellae (x 2670); c.) SEM-micrograph of a dehydrated mirabilite crystal (x 800), the upper right side is piled with an aluminosilicate overgrowth; d.) Sodium sulfate particles after the dehydration of mirabilite to thenardite (x 8000$)$.

balls of white crystals were found along vertical walls (5-W622, Fig. 8). The balls consist of transparent crystals, which form a skeletal structure like an open framework with voids, partly filled with tiny gypsum fibers. The growth of balls can be explained by seepage released from capillary tubes in the walls followed by evaporation (Hill \& Forti, 1997).

Beside calcium- and magnesium-bearing cave minerals one sodium sulfate speleothem was also identified in the White Hall. The single deposit of shiny crystals growing from the loamy ground in the SEentry of the White Hall was identified as mirabilite, $\mathrm{Na}_{2} \mathrm{SO}_{4} \cdot 10 \mathrm{H}_{2} \mathrm{O}$. The sample appears as transparent crystals, however, immediately after unwrapping from the air-tight transport tube, the surfaces of the crystals break out in white spots. The XRD diagram confirms the presence of thenardite, $\mathrm{Na}_{2} \mathrm{SO}_{4}$, the dehydrated form of mirabilite. Due to the dry laboratory conditions with a relative air humidity of less than $45 \%$, the dehydration process of mirabilite proceeds very quickly. According to the stability diagram presented by Hill \& Forti (1997, p. 192), mirabilite is not stable until the relative humidity is higher than $65 \%$ at $\mathrm{T} \sim 20^{\circ} \mathrm{C}$, but it is stable in the cave environment at $\mathrm{T}<10^{\circ} \mathrm{C}$. Unfortunately, neither the temperature nor the relative humidity was measured at the time of sample collection in the cave. In investigations by Haeseke-Knapzyk (1989) mirabilite in association with its dehydrated form thenardite was described from the Salzburgerschacht of the Gamslöcher-Kolowrat Cave system. Interesting details of the dehydration sequence are provided by the SEM micrographs. Single grains of the dehydrated phase thenardite still show crystal planes and edges of former mirabilite crystals (Fig. 9c), but the surfaces are not smooth and consist of aggregates of small particles, 1 to $3 \mu \mathrm{m}$ in size. Pores and cavities appear between the particles. Dehydration results in a decrease in volume of more than $50 \%$, if the ratios of the unit cell volumes of both phases are compared. The loosely accumulated particles of sodium sulfate shown in Fig. 9d are the result of the contraction due to the dehydration of mirabilite to thenardite. During the expeditions of the last three years no change in mineral deposits was observed.

In addition to the chemical composition of speleothems, the isotopic signature gives important indications as to their origin and their genesis. The ${ }^{34} \mathrm{~S} /{ }^{32} \mathrm{~S}$ ratios of the sulfate samples, gypsum needles (2-W63), mirabilite (4-W67), and gypsumballs (5-W622) were analysed by mass spectrometry. Surprisingly, the results show large isotopic variations. 
The sulfur stable isotope-value for sodium sulfate (or rather dehydrated mirabilite) is negative $\left(\delta^{34} \mathrm{~S}=\right.$ $-16.9 \%$ o) and similar to that of the gypsum needles found in the White Hall $\left(\delta^{34} \mathrm{~S}=-18.4 \%\right.$ o $)$. The $\delta^{34} \mathrm{~S}$ value for gypsum occurring in form of balls is $+2.9 \%$, indicating isotopically heavier sulfur. Low (negative) values imply a light sulfur isotope composition, which can be the result of kinetic effects during bacterial reduction of sulfate or by selective incorporation of light sulfur from a solution. High values of $\delta^{34} \mathrm{~S} \approx 20 \%$ o correspond to the enrichment of the heavy isotope ${ }^{34} \mathrm{~S}$ suggesting a genetic relation to marine sulfates (e.g., the large gypsum crystals in Pulpi, Spain; GarciaGuinea et al., 2002). $\delta^{34} \mathrm{~S}$ values around $0.0 \%$ are common for hydrothermal ore deposits. HasekeKnapczyk (1989) reported a $\delta^{34} \mathrm{~S}$ value of $+6.8 \%$ o for gypsum in the Salzburgerschacht and related its formation to iron-mineralization of pyrite and marcasite in the karst environment. He also described goethite pseudomorph after pyrite, but so far, no ironsulfide has been detected in the Gamslöcher-Kolowrat Cave. The different isotopic signatures of the samples clearly suggest different sulfate sources.

Spötl \& Pak (1996) analysed the isotopic composition of sulfur in Ca-sulfate evaporites of the Haselgebirge, the tectonic mélange of the Upper Permian and Lower Triassic of the NCA (Fig. 2). Samples of anhydrite and gypsum from locations at Dürrnberg and Moosegg, both a few $\mathrm{km}$ south of the Untersberg, have $\mathrm{\delta}^{34} \mathrm{~S}$ values ranging from $+10.8 \%$ o to $+12.7 \%$ vs. CDT. These values indicate a strong marine isotopic signal with isotopically heavier sulfur than in the samples of the Untersberg Cave. An immediate connection of the speleothems with sediments of the Haselgebirge can, therefore, be excluded. To our knowledge, no sulfur isotopic compositions from Upper Triassic formations of the NCA have yet been reported. Fanlo \& Ayora (1998) report ca. $+15 \%$ o for sulfates of the Upper Triassic seawater. The strongly negative isotopic values of the sodium sulfate and the gypsum needles can only be explained by a sole source of bacteriogenetic sulfur from sulfides. Such sulfides could occur in the Raibl Formation, and the relatively low elevation of the sample locations at 1031 and $1035 \mathrm{~m}$ within the cave system is in agreement with this interpretation. The positive sulfur values of the small gypsum balls at an elevation of $1070 \mathrm{~m}$ and of gypsum in the Salzburgerschacht at 1350 m elevation (Haseke-Knapczyk, 1989) are intermediate between typical sulfide and sulfate isotopic values and could be tentatively explained as a mixture of these two sources. Before reaching final conclusions on the sulfur source, sulfur isotopic investigations on sulfurbearing minerals from bedrocks are needed.

\section{CONCLUSIONS}

The mineralogical investigation of morphologically different, white-coloured speleothems sampled in the dry passages of the Gamslöcher-Kolowrat Cave shows the diversity of mineral phases in this cave environment. The strong airflow will probably be the major reason for the exceptional morphology and low density of calcite powder in the Desert section of the cave. An important task of further explorations will be the recording of temperature and humidity in the cave system. The analysis of the isotopic composition of the speleothems is the key factor to gaining information on the origin and genesis of the cave minerals. With the present state of knowledge, the unusually low sulfur isotopic compositional values of the sulfate mirabilite and some of the gypsum samples can be only speculatively explained by a sulfide source. Further investigations should be promising to answer the questions of origin and genesis of the mineral phases, their relationship to the Upper Triassic Raibl/ Cardita Formation, and the formation of the extremely dry cave parts in the Untersberg.

\section{ACKNOWLEDGEMENTS}

We are deeply grateful to Dirk Peinelt and Gerhard Zehentner (both LVHK Salzburg) for the impressive photographs taken during expeditions in the Gamslöcher-Kolowrat Cave system. We thank Gerti Friedl (University of Salzburg, Dept. of Geology) for support with the SEM. Bogdan P. Onac is gratefully acknowledged for performing the $\delta^{34} S$ analyses at the University of South Florida and Victor Polyak for cross-checking the $\delta^{34} \mathrm{~S}$ values at the University of New Mexico in Albuquerque, USA. We thank our anonymous reviewers for helpful comments that improved the manuscript.

\section{REFERENCES}

Bieniok A., Zagler G. \& Brendel U., 2010 - Speleothems in the Gamslöcher-Kolowrat Cave System, Untersberg (Austria). Acta Mineralogica - Petrographica, 6: 467. Bieniok A. \& Zagler G., 2010 - Mineralogische Untersuchung von Proben aus dem Weißen Saal (Gamslöcher-Kolowratsystem) und dem Blattlschacht vom Untersberg (Salzburg). Mineralogisches Archiv Salzburg, 13: 270-273.

Fanlo I. \& Ayora C., 1998 - The evolution of the Lorraine evaporite basin: implications for the chemical and isotope composition of the Triassic ocean. Chemical Geology, 146: 135-154.

Garcia-Guinea J., Morales S., Delgado A., Recio C. \& Calaforra J.M., 2002 - Formation of gigantic gypsum crystals. J. Geo. Soc., London, 159: 347-350.

Grassineau N., Mattey D. \& Lowry D., 2001 - Sulfur isotope analysis of sulfide and sulfate minerals by continuous flow-isotope ratio mass spectrometry. Analytical Chemistry, 73: 220-225.

Haseke-Knapczyk H., 1989 - Der Untersberg bei Salzburg. Ö.MaB-Programm (15), Universitätsverlag Wagner, Innsbruck, Austria, 223 p.

Hill C. \& Forti P., 1997 - Cave Minerals of the World. National Speleological Society, Huntsville, Alabama, USA, 463 p.

Kirchner E.C. \& Simonsberger P., 1982 - Nesquehonit und Hydromagnesit aus dem Salzburger Schacht des Untersberges, Salzburg. Der Karinthin, 87: 395-400.

Klappacher W. \& Mais K., 1975 - Salzburger Höhlenbuch. Landesverein für Höhlenkunde, Salzburg, Austria, 335 p.

Leitner C., Neubauer F., Urai J. L. \& Schoenherr J., 2011 - Structure and Evolution of a Rocksalt-MudrockTectonite: a case study of the Haselgebirge in the Northern Calcareous Alps. Journal of Structural Geology, accepted. doi:10.1016/j.jsg.2011.02.008 
Schlager M., 1930 - Zur Geologie des Untersberges bei Salzburg. Verhandlungen der Geologischen Bundesanstalt: 245-255.

Spötl C. \& Pak E., 1996 - A strontium and sulfur isotopic study of Permo-Triassic evaporites in the Northern Calcareous Alps, Austria. Chem. Geol., 131: 219-234.

Tollmann A., 1985 - Geologie von Österreich, Band 2: Außerzentralalpiner Anteil. Franz Deuticke, Wien, $710 \mathrm{p}$.
Uhlir C. \& Höck V., 2010 - www.untersberg.net. University of Salzburg, Div. Geology.

Zehentner G., 2010 - Das Gamslöcher-KolowratHöhlensystem (1339/1) am Untersberg, Forschungsergebnisse 2006-2010. Die Höhle, 61 (14): 102-108.

Zehentner G., Zagler G. \& Klappacher W., 2006 - Das Gamslöcher-Kolowrat-Salzburgerschacht-System (1339/1). Die Höhle, 57 (1-4): 90-102. 